\title{
COMMENT
}

\section{RIGHT OF ADOPTED GHILDREN TO TAKE UNDER ANTI-LAPSE STATUTES}

A testator bequeaths a legacy to his son and his residuary estate to other blood relatives. His son predeceases him, leaving an adopted child as his only heir. A statute in the jurisdiction provides that a legacy to a predeceased relative of a testator will not lapse, but will pass instead to the "issue" of the deceased beneficiary. This fact situation presents a question on which the courts have long disagreed:1 Does the adopted child qualify as "issue" within the statute, or does the legacy pass to the blood relatives or other takers of the residuary estate?

The problem brings two practical policies into sharp conflict. If the adopted child can take his parent's share in a legacy or devise under an anti-lapse statute, childless persons may adopt children in order to prevent blood relatives from receiving property which perhaps should rightfully remain in the blood line. ${ }^{2}$ On the other hand, if the adoptive parent lives one day longer than the testator and then dies intestate, the adopted child takes the property as his heir, and consequently there is no valid reason to prevent the child from taking under the anti-lapse statute if the beneficiary happens to predecease the testator. ${ }^{3}$

The present trend, both in the legislatures and in the courts, has been to give increasingly broad rights of inheritance to adopted children.

\section{History of Adoption Statutes}

The English common law did not recognize adoption. ${ }^{4}$ Rather, the passage of property from generation to generation was tied closely to

${ }^{2}$ See 4 PAGE, WILIS § 1425 (3d ed. 194I); Comment, 25 Calif. L. Rev, 81, 85 (1936). For an excellent, although somewhat outdated discussion of the rights of adopted children in this and related areas see Oler, Construction of Private Instruments Where Adopted Children Are Concerned (pts. 1-2), 43 Mich. L. REv. 705, 901 (1945).

2 See In the Matter of the Estate of Martin, 133 Misc. 80, 83, 230 N.Y. Supp. 734, 737 (1928).

${ }^{3}$ See In the Matter of the Estate of Walter, 270 N.Y. 201, 205, 200 N.E. 786, 787 (1936); In the Matter of the Estate of Foster, 108 Misc. 604, 609, 177 N.Y. Supp. 827,830 (19x9).

2 Pollock \& Maitland, The History of English Law 399 (2d ed. r898). The continental custom of "mantle-children" evidently was practiced occasionally until it was rejected by the court of Henry II. This custom permitted parents to adopt on 
blood lines. Thus, in the middle of the thirteenth century, Bracton wrote:

Likewise the right [of inheritance] descends to the true heir, . . . for God alone makes an heir, and because the heir is called from the inheritance, and not the inheritance from the heir."

The civil law countries, however, permitted adoption under a system derived from the ancient Greeks and Romans. ${ }^{6}$

There were no provisions for adoption by judicial proceedings in the United States until I85I, when Massachusetts enacted the first general adoption statute. ${ }^{7}$ The Massachusetts act gave adopted children the same rights they would have had if born to the adopting parents in lawful wedlock, "saving only that such child shall not be deemed capable of taking property expressly limited to the heirs of the body or bodies of such petitioner or petitioners [adopting parents]."8 This proviso, copied in many of the adoption statutes of other states, ${ }^{9}$ reflected the reluctance on the part of the legislatures to include adopted children in the blood line of the adoptive parents.

Legislatures, however, gradually began to invest adopted children with more of the rights of natural children. As early as I895, North Dakota replaced a provision that adoption itself should not constitute a child the heir of the adoptive parents ${ }^{10}$ with a clause stating that the adopted child shall be the "same as if born to them [the adoptive parents] in lawful wedlock." "In I9I7 Pennsylvania enacted a statute which provided that an adopted child could inherit "from and through" his adoptive parents. ${ }^{12}$

The history of the New York adoption statute reflects the changing attitude of the legislatures through the years, although it does not at the present time give as broad rights as do the majority of states. The first New York adoption statute was enacted in $1873,{ }^{13}$ but adopted

the occasion of their marriage any pre-existing offspring. The parents and any children were placed under a cloak during the marriage ceremony and thus the offspring became "mantle-children." Id. at 397 .

- Bracton, i de Legibus et Consuetudinibus Angliae, Libri Quinque 497-98 $(1878)$.

1 AM. Jur. Adoption of Children $\S_{3}(1936)$; I C.J. Adoption of Children $\S_{2}$ (1914).

${ }^{7}$ Mass. Acts \& Resolves 185 I, ch. 324 .

${ }^{8} I d$. at $\$ 6$.

${ }^{\circ}$ E.g., ME. Rev. Stat. ANN. ch. 158, $\$ 40$ (r954); N.H. Rev. Stat. AnN. $\$ 46 \mathrm{r}: 6$ (1955).

${ }^{10}$ N.D. Laws $189 \mathrm{x}$, ch. $4, \S 6$.

${ }^{21}$ N.D. REV. CODE $\$ 2804$ (x 895 ).

${ }^{18} \mathrm{~Pa}$. Laws I9I7, no. 192, $\$$ 16(b).

${ }^{13}$ N.Y. Sess. Laws 1873 , ch. 830 . 
children were not able to inherit from their adoptive parents until I $887,{ }^{14}$ and the heirs of an adopted child did not receive this right until $1896 .^{18}$ In 1938 , adopted children and natural children were granted all the rights of the family relationship, including the right of inheritance. $^{16}$ The present statute establishes the legal relation of parent and child between an adopted child and his adoptive parents, including the rights of inheritance from each other, but it provides that as to the passing of property dependent on the foster parent dying without heirs, "the foster child is not deemed the child of the foster parent so as to defeat the rights of remaindermen."17

Most of the states recently have re-considered their adoption laws, and a majority purport to give an adopted child the same legal rights as natural children or as if born to the adoptive parents in lawful wedlock, ${ }^{18}$ while a large number permit a child to inherit from and through his adoptive parents. ${ }^{19}$ Many of these statutes have been enacted within the past ten years, ${ }^{20}$ and although a substantial number of states are still hesitant to grant a child the legal status of blood relative of the entire adoptive family, the trend is clearly toward giving the adopted child rights equal to those of natural children.

\section{Classification of Anti-Lapse and Adoption Statutes}

The purpose of anti-lapse statutes, which have been enacted in nearly all jurisdictions, ${ }^{21}$ is to make provision for certain relatives of a testator

\footnotetext{
${ }^{26}$ N.Y. Sess. Laws 1887 , ch. 703. However, the natural parents retained rights to the adopted child and his property until 1909, N.Y. Laws 1909, ch. 19, and even today the child is permitted to inherit from his natural parents, N.Y. DoM. REL. LAW $\S$ II\%.

${ }^{18}$ N.Y. Sess. Laws 8896, ch. $272, \S 64 .{ }^{18}$ N.Y. Sess. Laws 1938, ch. $606, \S 115$.

${ }^{27}$ N.Y. DOM. REL. LAW $\$ 117$. This statute was re-enacted without change in I961.

${ }^{18}$ E.g., KY. REv. Stat. § 199.520(2) (1960), N.J. Stat. ANN. § 9:3-30B (1960), N.D. Century Code AnN. \& 14-11-13 (1960).

${ }^{10}$ E.g., Cal. Prob. Code $\S 257$, N.C. Gen. Stat. $\$ 48-23$ (Supp. 196r). In a state with an adoption statute like this, there should be no question but that an adopted child takes under an anti-lapse statute, since this is closely analogous to his inheriting through an adoptive parent. See text accompanying note 39 infra.

${ }^{20}$ Twenty-six states have enacted statutes similar to the two types mentioned within the past ten years. This trend reflects a great shift of authority. In 1933 Professor Mechem wrote concerning anti-lapse statutes: "Where adoption is involved, the cases are not in harmony. Courts in general, with a respect for 'the blood' hardly to be paralleled outside of eighteenth century literature, take the view that kinship (at least for the purposes of succession) is created only as between the parties to the adoption." Mechem, Some Problems Arising Under Anti-Lapse Statutes, 19 Iowa L. REv. I, 5 (r933).

${ }_{21}$ Statutory research indicates only four states which do not have anti-lapse statutes: Hawaii, Louisiana, New Mexico and Wyoming.
} 
to whom he presumably would have made a legacy or devise had he known that one of his beneficiaries had predeceased him."2 These laws generally state that if a beneficiary with a certain relationship to the testator should predecease him, then the issue of descendants of the beneficiary take the share he would have taken had he survived. Whether an adopted child will qualify under an anti-lapse statute generally depends upon the interpretation of that statute in conjunction with the state's adoption statute. ${ }^{23}$

A majority of anti-lapse statutes require that a person be the "issue" of the deceased beneficiary in order to prevent lapse. ${ }^{24}$ The word "issue" historically has connoted a blood relationship, ${ }^{25}$ a notion which has given the courts some difficulty. ${ }^{26}$ Other statutes state that the person claiming the deceased beneficiary's share must be a "descendant" or "lineal descendant" of the beneficiary. ${ }^{27}$ The implication of a blood connection is diffcult to overcome under these statutes also, ${ }^{28}$ but here

\footnotetext{
${ }^{22} 4$ PAGE, WILLS $\$ 1422$ at 176 (3d ed. 1941).

${ }^{23}$ Flynn v. Bredbeck, 147 Ohio St. 49, 55, 68 N.E.2d 75, 78 (1946).

24 There are twenty-two statutes with this requirement. Colo. REv. STAT. ANN. \$152-5-1 I (1953); Conn. Gen. Stat. ANN. \$ 45-176 (1960); Del. CODE ANN. tit. $12, \$ 2313$ (1953); D.C. CODE ANN. \$19-110 (1961); GA. CODE ANN. \$ 1 $33-812$ (1959); KaN. Gen. Stat. ANN. \$59-615 (1949); KY. Rev. Stat. \$ 394.400 (1960); Mass. ANN. Laws ch. I91, $\$ 22$ (1955); Mich. Comp. Laws $\S 702.11$ (1948); Minn. Stat. ANn. \$525.203 (1947); NeB. Rev. Stat. \$ 30-228.03 (1956); N.C. Gen. Stat. $\$ 33^{1-42.1}$ (Supp. 1961); N.D. Century Code ANN. \$ 56-04-20 (1960); OHIo Rev. Code ANN. $\$ 2107.52$ (1954); PA. Stat. ANN. tit. $20, \S 180.14(8)$ (1950); R.I. GEN. LAws ANN. $\$ 33-6-19$ (1956); S.C. CODE \$ 19-237 (1952); TENN. CODE ANN. \$ 32-306 (1955); VT. STAT. ANN. tit. I4, $\S 55^{8}$ (1958); VA. Code ANN. $\S 64-64$ (1950); W.VA. Code ANN. $\$ 4054$ (1961); WIs. STat. $\$ 238.13$ (1957).

${ }_{25}$ See In re Miller's Trust, 133 Mont. 354, 356-58, 323 P.2d 885, 886-87 (1958); In re Semon's Will, r95 Misc. 938, 940, 91 N.Y.S.2d 203, 206 (1949). See also 4 PAGE, WILLS $\$ 34.22$ (Bowe-Parker ed. 196r).

${ }^{20}$ See, e.g., Arnold v. Helmer, 327 Mass. 722, 100 N.E.2d 886 (1951) (adopted child is not issue), In re Miller's Trust, 133 Mont. 354, 323 P.2d 885 (I958) (adopted child is not issue), Flynn v. Bredbeck, 147 Ohio St. 49,68 N.E.zd 75 (1946) (adopted child is issue).

${ }^{27}$ Fifteen statutes have this wording. Alaska Comp. LAwS ANN. $\$ 59-4-3$ (1949); Cal. Prob. Cone $\S 92$; Fla. Stat. Ann. $\$ 731.20$ (Supp. 1961); Idaho CODE ANN. § I4-323 (1948); Ill. ANn. Stat. ch. 3, § 49 (Smith-Hurd 1961); IND. ANN. Stat. $\$ 6-601(\mathrm{~g})(2)$ (1953); ME. Rev. Stat. ANn. ch. 169, § 10 (1954); Mo. ANN. Srat. \$ 474.460 (1956); Mont. Rev. Codes ANN. \$ 91-139 (1949); Nev. Rev. Stat. $\$ 133-200$ (Supp. 1960); OKLA. Stat. AnN. tit. 84, $\$ 142$ (1952); ORE. Rfv. Stat. $\$ 114.240$ (Supp. 1957); S.D. CODE § 56-0232 (1939); UTAH Code ANN. $\$ 74^{-1-35}$ (1953); WASH. Rev. CODE $\$ 11.12 .110$ (Supp. 1959).

${ }_{28}$ "'The word 'descendants' connotes those persons who are in the blood stream of the ancestor." In re Hewett's Estate, I53 Fla. 137, 142, 13 So. 2 d 904,907 (1943).
} 
the courts seem to have accomplished the task with more facility than in the "issue" jurisdictions. ${ }^{29}$ A few states require that the petitioner be a "child" of the legatee, ${ }^{30}$ and two provide that he must be an "heir." In these states, an adopted child will prevent lapse, since all states provide that an adopted person is the child and heir of his adopting parents. ${ }^{32}$

Maryland has by far the broadest anti-lapse statute. It provides that if any devisee or legatee shall predecease the testator, then the devise or legacy shall have the same effect "as if such devisee or legatee had survived the testator."33 Adopted children clearly prevent lapse under the Maryland statute, as it is well-settled that they are heirs of their adoptive parents.

The statutes of three states specifically provide that adopted children prevent lapse. The Indiana anti-lapse statute reads: "The word 'descendant' . . shall include children adopted during minority by the testator and by his descendants. ... ."34 Arkansas $^{35}$ and Pennsylvania ${ }^{36}$ have similar provisions which include all persons, whether or not adopted during minority.

A few other states have statutes which define the words "issue,"

A descendant has also been defined as "a person who proceeds from the body of another. ..." Black, LaW Dictionary (4th ed. 1951).

${ }^{20}$ See, e.g., In re Moore's Estate, 7 Cal. App. 2d 722, 47 P.2d 533 (1935); Hoellinger v. Molzhon, 77 N.D. 108, 41 N.W.2d 217 (1950). But see, In re Hewett's Estate, 153 Fla. 137, 13 So. 2d 904 (1943).

${ }^{30}$ There are seven statutes of this type. AlA. CODE tit. 61, $\$ 16$ (1960); ARK. Stat. ANN. § 60-410(b) (Supp. 1961); ARIz. Rev. Stat. ANN. \& 14-133 (1956); Miss. Code ANN. $\S 660$ (1957); N.J. Rev. Stat. $\S{ }_{3} A: 3-13$ (1953); N.Y. DECED. Est. LaW § 29; Tex. Prob. CODE § 68 (1956).

${ }^{81}$ IOWA CODE ANN. § 633.16 (1946); N.H. Rev. Stat. ANN. § $551: 12$ (1955) (heir in the descending line).

${ }^{82}$ Since there was no adoption under the common law, an adopted child can inherit from his adopting parents only if the adoption statute so provides. 2 C.J.S. Adoption of Children $\S 66_{3}(\mathrm{a})$ (1936). See also I AM. Jur. Adoption of Ghildren $\S 59$ (1936). Statutory research indicates that all states permit an adopted child to inherit from his adopting parents.

${ }^{38}$ MD. ANN. CODE art. $93 \S 354$ (1957).

84 IND. ANN. STAT. \& 6-601 (g) (2) (1953).

${ }^{35}$ ARK. STAT. ANN. $\S 60-4$ Io(b) (Supp. 1961). This statute reads: If "such devisee shall die in the lifetime of the testator, leaving a child, natural or adopted, ... such devise shall not lapse. ..."

${ }^{36}$ PA. STAT. ANN. tit. 20, $\S 180.14$ (6) (Supp. 1961). This statute states: "In construing clauses (8), (9), and (10) of this section, relating to lapsed and void devises and legacies, . . . any person adopted before the death of the testator shall be considered the child of his adopting parent...." 
"descendants," or "child" to include adopted children. ${ }^{37}$ These statutes, read in conjunction with the anti-lapse statutes, make it clear that an adopted child will prevent lapse. ${ }^{38}$

In most jurisdictions, however, it is necessary to examine the relationship established by the adoption statute to determine whether an adopted child can qualify as "issue" or "lineal descendant" under the anti-lapse statute. Adoption statutes fall into four general classifications.

\section{"From and Through" Statutes}

"From and through" statutes provide broadly that adopted children are to inherit through as well as from their adoptive parents. These statutes, of which the California act is typical, generally state that an adopted child is to be treated in all respects as a natural child of the adoptive parents. The California Probate Code provides: "An adopted child shall be deemed a descendant of one who has adopted him, the same as a natural child, for all purposes of succession by, from or through the adopting parent the same as a natural parent."39 A common variation of this provision is found in the Delaware statute, which gives an adopted child "the right to inherit from its adoptive parent or parents and from the collateral or lineal relatives of such adoptive parent or parents. ....340

A child adopted under a statute of this type clearly should prevent lapse of a legacy or devise, since the legislature undoubtedly intended to include adopted children in the blood line of the adoptive family.

The legislatures only recently have begun to break away from the traditional notion that adopting parents should not be allowed to force on their other kindred a relationship with the adopted child. Of the twenty-one ${ }^{41}$ "from and through" statutes in effect in the United States

${ }^{37}$ See Conn. Gen. Stat. ANn. § 45-65a (1960); D.C. Code ANn. § 16-224 (1961); Tex. Prob. Code $\S 3$ (b) (1956); Wash. Rev. Code $\S 11.04 .020$ (Supp. 1956).

${ }^{8 s}$ For example, the Connecticut anti-lapse statutes states that if a child, grandchild, brother or sister of the testator predeceases him, then "the issue of such devisee or legatee shall take the estate so devised or bequeathed," ConN. Gen. STAT. ANN. § 45-176 (1960), and another Connecticut statute provides that the word "issue" includes adopted persons, Conn. Gen. STAT. ANn. \& 45-65a (1960).

${ }^{80}$ CAL. PROB. CODE $§ 257$.

${ }^{\circ}$ DeL. CODE ANn, tit. 13, § 920(b) (1953).

${ }^{41}$ Cal. Prob. Code $\&$ 257; Conn. Gen. Stat. Ann. \& 45-65 (1960); Del. Cone ANN. tit. 13, § 920 (1953); D.C. CODE ANN. § 16-222 (1961); Ill. ANN. Stat. ch. $3, \S_{14}$ (Smith-Hurd 1961); MD. ANN. CoDE art. 16, § 78 (Supp. 1961); MicH. Comp. Laws \& 710.9 (Supp. 1956); Minn. Stat. Ann. $\$ 259.29$ (1959); Miss. Code ANN. § 1269-06 (Supp. 1960); MO. ANN. Stat. § 453-090 (1952); NEB. Rev, StAT. 
today, seventeen ${ }^{42}$ have been enacted since 1950.

\section{"Natural Children" Statutes}

Another class of statutes purports to give an adopted child all the rights of a natural child born in lawful wedlock, but do not expressly provide for inheritance through the adoptive parents from other lineal or collateral kindred."3 Arguably these statutes render the child the "natural child" of the adopting parents only, and not the natural kindred of other relatives of the adopting parents. However, when the adoption statutes are construed in conjunction with their respective anti-lapse statutes, it is evident that in most of these states an adopted child probably would prevent lapse. For example, the Alaska ${ }^{44}$ and Washington ${ }^{45}$ adoption statutes make an adopted child the issue of his adopters, and the anti-lapse statutes ${ }^{46}$ require that a person be a lineal descendant of the beneficiary in order to prevent lapse. It would be difficult to construct a plausible argument that one who is issue of another person is not also his lineal descendant.

These statutes also are relatively recent. Nine $e^{47}$ of the seventeen ${ }^{48}$ "natural child" statutes have been enacted since 1950.

§ 43-110 (1960); NEV. REV. STAT. § 127.160 (Supp. 1959); N.C. GEN. STAT. $\S 48-23$ (Supp. 196I); OKLA. STAT. ANN. tit. 10, $\$ 60.16$ (I) (Supp. I961); ORE. Rev. Stat. § 109.04I (Supp. I96I), § III.210 (Supp. I957); PA. STAT. ANN. tit. 20, § 1.8 (1950); R.I. GEN. LAws ANN. \$ 15-7-16 (1956); TEX. REv. Civ. Stat. ANN. art. $46 \mathrm{6}(9)$ (1959); VA. CODE ANN. $\$ 63-358$ (Supp. 1960); W. VA. CODE ANN. $\S 4759$ (1961); WIS. STAT. $\$ 48.92$ (1957).

${ }^{42}$ The four states which have statutes enacted before 1950 are Delaware (1935), Missouri (1947), Nebraska (1943), and Pennsylvania (1917).

${ }^{13}$ Although the wording of these statutes varies considerably, the Kentucky act is a good example. It provides that an adopted child "shall be considered for purposes of inheritance and succession and for all other legal considerations, the natural, legitimate child of the parents adopting it the same as if born of their bodies." Kr. REv. STAT. $199.520(2)$ (1960).

"Alaska Comp. Laws ANn. § 21-3-21 (1949).

${ }^{40}$ WASH. Rev. CODE $§ 26.32 .140$ (Supp. 1959).

15 Alaska Comp. Laws ANN. § 59-4-3 (1949); Wash. Rev. Code § 11.12.110 (Supp. 1959).

"Alabama (1956), Arizona (1952), Colorado (1953), Florida (1953), Hawaii (1953), Kentucky (1956), New Jersey (1953), South Carolina (1954), and Washington (1955).

${ }^{48}$ ALA. CODE tit. 27, $\S 5$ (Supp. 1959); Alaska Comp. Laws ANN. $\S 21$ 1-3-21 (1949); ARIz. Rev. Stat. ANn. § 8-108 (Supp. 1961); ARK. Stat. ANN. § 56-109 (1947); Colo. Rev. Stat. ANn. § 152-2-4 (1953); Fla. STAT. ANN. $\$ \S 72.22,731.30$ (Supp. 1961); GA. Code ANN. § 74-414 (Supp. 196I); HAWAII Rev. LAWs § 331-16 (1955); IND. ANN. STAT. § 3-121 (1953); IOWA CODE ANN. § 600.6 (1946); KAN. Gen. Stat. ANN. § 59-2103 (1949); Kr. Rev. Stat. § 199.520(2) (1960); N.J. REv. STAT. § 9:3-30B (1960); N.M. STAT. ANN. §§ 22-2-10, 29-1-17 (1953); N.D. 


\section{"Parent-Child" Statutes}

A few statutes merely establish the legal relation of parent and child between the adopting parent and the child, and contain no statement of policy intended to further equate such children with natural children. ${ }^{49}$ Since the statute does not purport to make an adopted child a member of the entire adoptive family, it is doubtful that an adopted child will prevent lapse under this type of statute. Only five states have adoption statutes of this nature, and none have been passed since $1945 .^{.00}$

\section{"Limitation" Statutes}

Statutes in eight jurisdictions juxtapose some limitation on the inheritance rights of adopted children created by provisions of the types discussed above. ${ }^{51}$ The Louisiana act, for example, states that "as between the adopted and his lawful issue, and the blood relatives of the adopter, no legal relationship whatsover shall arise. . . ."52 Four other states prohibit an adopted child from taking property expressly limited to heirs of the body of the adopting parent..53

The decisions are conflicting in "limitation" states as to the right of an adopted child to take under an anti-lapse statute. ${ }^{54}$ This can be explained by the variations in the other clauses of the adoption acts, which range from the "parent-child" relationship established by the

CENTURY CODE ANN. § 14-11-13 (1960); S.C. CODE § 19-52.1 1 (Supp. 1960); WASH. REV. CODE $§ 26.32 .140$ (Supp. 1958).

49 The Utah act is typical of this type of statute; it reads: "after adoption the two [adopting parent aud adopted child] shall sustain the legal relation of parent and child, and have all the rights and be subject to all the duties of that relation." UTAH CODE ANN. \& 78-30-10 (1953).

${ }^{80}$ IDAHO CODE ANN. § 16-1507 (Supp. 1961), § 16-1508 (1948); MONT. REV. CODE ANN. §61-134 (1947); [S.D. CODE § 14-0407] (Supp. 1960); UTAH CODE ANN. § 78-30-10 (1953); [WYo. CoMp. Stat. ANN. §§ I-712, I-72I (1945).]

${ }^{82}$ LA. Civ. CODE ANN. art. 214.2 (Supp. 1955); ME. REv. STAT. ANN. ch. 158, \& 40 (1954); Mass. ANN. Laws ch. $210, \S 7$ (1955); N.H. Rev. Stat. ANN. \& 461:6 (1955); N.Y. Dom. REL. LAW § 117 (1957); OHIO REv. Code ANN. $\S 3107.13$ (1960); TENN. CODE ANN. $\S 36-126$ (Supp. 1961); VT. Stat. ANN. tit. $15, \S 448$ (1958).

"LA. Civ. CODE ANN. art. 214.2 (Supp. 1955).

${ }^{88}$ ME. Rev. STAT. ANN. ch. 158, § 40 (1954); N.H. REv. STAT, ANN, § $461: 6$ (1955); Ohio Rev. Code ANN. \& 3107.13 (1960); VT. Stat. ANN. tit. 15, \& 448 (1958).

"Compare Warren v. Prescott, 84 Me. 483, 24 Atl. 948 (1892) (prevents lapse), with Gammons v. Gammons, 212 Mass. 454, 99 N.E. 95 (19I2) (does not prevent lapse). 
New York statute" to the broad "from and through" provisions in the Ohio act.

These limitations have been retained from early adoption statutes. As has been noted, the new adoption laws are generally liberal; as more legislatures re-evaluate their adoption statutes, greater inheritance rights for adopted children can be anticipated.

\section{Judicial Construction}

The courts have been more generous in granting inheritance rights to adopted children than have the legislatures, although the specific problem of whether an adopted child will prevent lapse of a legacy or devise has not been passed on in all jurisdictions. A majority of the courts which have considered the question now hold that an adopted child will prevent lapse. The reasoning by which the courts have arrived at this conclusion, however, varies as greatly as the statutes under which the decisions are made.

. One approach taken by the courts has been to distinguish anti-lapse statutes from inheritance laws and thus hold that since restrictions in adoption statutes generally are related to the child's right to "inherit" and not to his right to take under a will, these limitations are immaterial when an anti-lapse statute is involved. The leading case is Warren $v$. Prescott, ${ }^{87}$ an 1892 Maine decision which has only recently gained a large following. The court, deciding the case under a "limitation" statute, ${ }^{58}$ explained this distinction:

In such a case, a child born in lawful wedlock does not "inherit" the devise or legacy from his parents' kindred. One who takes under a will does not "inherit." ... He takes as a lineal descendant of the legatee, by force of the statute..$^{59}$

\footnotetext{
${ }^{B S}$ NEW YORK DOM. REL. LAW $\S$ I 5 . This statute provides: "The foster parents or parent and the foster child shall sustain toward each other the legal relation of parent and child and shall have all the rights and be subject to all the duties of that relation including the rights of inheritance from each other."

${ }^{\text {so }}$ OHIO REv. CODE ANN. $\$ 3$ 107.13 (1960). This statutes reads: “. . . a legally adopted child shall have the same status and rights, and shall bear the same legal relationship to the adopting parents as if born to them in lawful wedlock. ..."

${ }^{87} 84$ Me. 483,24 Atl. 948 (1892).

${ }^{68} \mathrm{Me}$. Laws 1880, ch. 183 .

${ }^{80}$ Warren v. Prescott, 84 Me. 483, 487, 24 Atl. 948, 949 (1892), which held that since the limitations in the adoption statute related to the child's right to "inherit" and not to his right to take under a will, an adopted child could take under the anti-lapse statute, which was distinguished from the inheritance laws because it did not involve intestacy.
} 
This is a fine distinction, and it is questionable whether it is intellectually sound as stated by the Maine court. Inheritance is entirely statuatory, and it too amounts to no more than taking as a relative of the intestate by force of the statute.

An Illinois court, in In re Harmount's Estate, ${ }^{60}$ somewhat clarified the distinction which the Maine court was attempting to articulate. The court stated:

[T] he adopted children are not seeking to take property from the mother of their adoptive father but are seeking to take as substituted legatees that share which had been given by will to their adopting father. ... While it is true that the children are seeking to take property which had its origin in the estate of the adopting father's deceased ancestor, the adopted children are taking by virtue of a statute which creates in them an original right by virtue of their substitution for the legatee who predeceased the testatrix. ${ }^{61}$

There the anti-lapse statute was viewed not as a statute of descent, but rather as a statute which narrows the circumstances under which a legacy or devise will lapse. ${ }^{6: 2}$ This rationale, while effective in reaching an equitable result, approaches the problem by the back door and does not really elucidate the rights of an adopted child.

The North Dakota court, in Hoellinger v. Molzhon, ${ }^{63}$ approached the problem from the standpoint of the policies the statutes are intended to serve. The court found that the legislative purpose of the anti-lapse statute was to prevent hardships caused by the virtual disinheritance of children when a legacy or devise lapsed. ${ }^{64}$ The court then held that the adoption law, a "natural child" statute, was intended to grant all children equal inheritance rights whether they came into the line of descent by birth or by adoption. ${ }^{65}$ Considering the purposes of the two statutes together, the court found it evident that adopted children should prevent lapse. This reasoning could also be applied to a "parentchild" statute, since hardships created by the lapse of a legacy or devise are as great when the adopted person is just a "child" of the adopting

${ }^{60} 336$ Ill. App. 322, 83 N.E.2d 756 (1949).

12 Id. at 325-26, 83 N.E.2d at 758 . (Emphasis added.)

os Id. at 326,83 N.E.2d at 758 .

${ }^{68} 77$ N.D. 108, 41 N.W.2d 217 (1950).

"Id. at III, 4I N.W.2d at 219 .

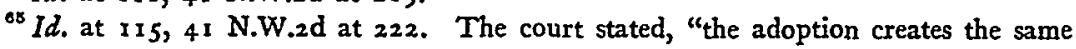
rights of heirship in the adopted child as in the child of the body. The ordinary meaning of 'lineal descendant' therefore, does not apply here." Id. at 112,41 N.W.2d at 220 . 
parent as when he is a "natural child." By analogous reasoning the same result could obtain under a "limitation" statute. ${ }^{.6}$

In 196I the North Carolina Supreme Court held, in Headen v. Jackson, ${ }^{67}$ that an adopted child prevents lapse under that state's "from and through" statute ${ }^{88}$ and approved a simple test for arriving at that result.

Whatever the problem is concerning an adopted child, his standing and his legal rights can be measured by this clear test: "What would his standing and his rights be if he had been born to his adoptive parents at the time of the adoption?" $" 9$

This test is easy to apply and can readily be utilized in solving problems which arise under any of the "from and through" or "natural child" statutes. It is by far the best solution to the problem of the status of adopted children under anti-lapse statutes. Unfortunately, the test does not solve anti-lapse problems under "parent-child" or "limitation" statutes.

The New York courts have struggled with the anti-lapse problem under a "limitation" statute ${ }^{70}$ for years, and have reached conflicting results. In I9r9 a lower New York court held that an adopted child would prevent lapse, stating that the legislature had intended that an adopted child take under the anti-lapse statute. ${ }^{71}$ In 1928 , however, the New York Appellate Division affirmed In the Matter of Estate of Martin, ${ }^{72}$ where the lower court had held that as a matter of public

${ }^{\circ 0}$ The court could examine the policies behind both the anti-lapse statute and the adoption statute. In a "limitation" state these statutes would probably be found to conflict and the court would have to make a choice between the two. By finding that the policy of preventing hardship to children of deceased beneficiaries was stronger than the policy of keeping property in the blood line, the court could reach the conclusion that adopted children should prevent lapse under a "limitation" statute.

${ }^{67} 255$ N.C. 157,120 S.E.2d 598 (1961). Accord, In re Holcombe's Estate, 259 Wis. 642,49 N.W.2d 914 (195I).

${ }^{88}$ N.C. GEN. STAT. § 48-23 (Supp. 1961).

${ }^{\circ 2} 255$ N.C. $157,159,120$ S.E.2d $598,599-600$ (1961). The court quoted from Adoption of Minors, $A$ Survey of Statutory Changes in North Carolina in re55Adoption of Minors, 33 N.C.L. REv. 521,522 (1955).

${ }^{\circ 0}$ N.Y. DOM. REL. LAW § 117 .

"In the Matter of the Estate of Foster, 108 Misc. 604, 177 N.Y. Supp. 827 (Surr. Ct. I9Ig). The court reasoned that the right to take property on the death of an ancestor is not an inherent right, but a statutory one. Id. at 612,177 N.Y. Supp. at 832 .

${ }_{72} 224$ App. Div. 873, 230 N.Y. Supp. 873 (1928), affirming 133 Misc. 80, 230 N.Y. Supp. 734 (Surr. Ct. 1928). 
policy, an adopted child could not prevent lapse. ${ }^{73}$ The lower court said that it would be deleterious to public policy if an adopted child, perhaps unknown to the testator, could defeat the testator's intent in making a disposition of his property. ${ }^{74}$ In $1935 \mathrm{a}^{\circ}$ lower New York court held, without expressly overruling the Martin case, ${ }^{75}$ that an adopted child prevented lapse, ${ }^{76}$ and one year later the New York Court of Appeals, expressly overruling the Martin case, held that an adopted child was the "child" of his foster parents within the meaning of the anti-lapse statute. ${ }^{77}$ New York law, which now appears to be settled, has supplied the most practical reasoning for the solution of this problem. Their courts have pointed out that since an adopted child would have taken the property had the beneficiary outlived the testator by even a day, there is no reason to let a legacy or devise lapse merely because the beneficiary happens to predecease the testator. ${ }^{78}$

Several states, however, still hold that an adopted child will not prevent lapse. Massachusetts has consistently held that under its limitation statute a legacy or devise lapses if a beneficiary is survived only by an adopted child. In Arnold $v$. Helmer, ${ }^{79}$ the court stated that the statute created a relationship between the child and the adopting parents but did not intend "to force that relationship or its consequences upon other kindred." ${ }^{180}$ In Rauch v. Metz, ${ }^{81}$ a Missouri court refused to permit an adopted daughter to take a legacy bequeathed to her deceased adoptive mother, holding that the "blood of a testator was

${ }^{78}{ }_{133}$ Misc. 80, 83, 230 N.Y. Supp. 734, 737 (Surr. Ct. 1928).

"Ibid.

${ }^{78}$ In the Matter of the Estate of Horvath, 155 Misc. 734, 737-38, 279 N.Y. Supp. 189, 193 (Surr. Ct. 1935). Here the court stated that the Martin case was incorrect and appeared to have been overruled already in Matter of Horn, 256 N.Y. 294, 176 N.E. 399 (193I). The Horn case, however, merely held that an adopted child could take under a will leaving property to the children of the beneficiaries in the event that the beneficiaries should predecease the testator, and the court did not even mention the Martin case.

${ }^{70}$ In the Matter of the Estate of Horvath, supra note 82.

${ }^{77}$ In the Matter of the Estate of Walter, 270 N.Y. 201, 200 N.E. 786 (1936). The court quoted In the Matter of the Estate of Cook, 187 N.Y. 253, 261, 79 N.E. 991, 994 (1907): "In the eye of the law, therefore, adopted children are lineal descendants of their foster parent. They are in the line of descent from him through the command of the statute, the same as if that line had been established by nature." In the Matter of the Estate of Walter, supra at 204, 200 N.E. at 787.

${ }^{78}$ In the Matter of the Estate of Walter, supra note 84 at 205 , 200 N.E. at 787; In the Matter of the Estate of Foster, 108 Misc. 604, 609, 177 N.Y. Supp. 827, 830 (Surr. Ct. 1919).

\footnotetext{
${ }^{70} 327$ Mass. 722, 100 N.E.2d 886 (1951).

${ }^{80}$ Id. at 724 , 100 N.E.2d at 887 .

${ }_{81} 212$ S.W. 357 (Mo. 1919).
} 
the key to his intention, ${ }^{382}$ and that the legislature did not intend to "divert his provision for his relatives to channels outside the flow of his own blood."83 This emphasis on the necessity for a blood relationship is losing ground and hopefully will disappear under the influence of the majority view.

\section{Analysis of Underlying Policies}

The weight of authority today is definitely in favor of permitting an adopted child to take under an anti-lapse statute. This is a sound view from the standpoint of public policy. The interest of the public in providing a workable system for incorporating unwanted and orphaned children into society and in giving them all the benefits of children born into a family in lawful wedlock must be balanced against any family interest in keeping property in the blood line and protecting against adoption of strangers to the blood for the sole purpose of preventing a possible reversion or lapse of a legacy or devise. The public interest is augmented by a desire on the part of the adopting parents to treat the adopted child in all respects as if he were their natural child. No distinction is made between adopted children and natural children in any other respect; it seems unnecessary to treat them differently as to inheritance.

Today there is less necessity for keeping property within the family blood ties. The socio-economic structure of the United States is different from that of common law England. Most wealth in England was in the form of land, tied to the blood by the feudal system. Thus, land, for reasons of security, could not be divided, even within the family. However, in the United States the bulk of modern wealth is composed of securities and other forms of personal assets, which need not be kept intact in an economic unit, and which often have no particular family ties.

The possibility that some people will adopt children solely to defeat the rights of blood relatives is negligible. Certainly the danger is not so great as to outweigh the strong policy in favor of giving adopted children broad inheritance rights. Moreover, if a testator is concerned about this problem, or feels strongly that property should remain in the blood line, there is, of course, nothing to prevent him from disinheriting an adoptive grandchild or including a provision in his will that no adopted persons are to take property passing under his will.

${ }^{82} 1 d$. at 367 .

${ }^{83}$ Ibid. 
There is no apparent reason to subvert the public interest for those few persons who can adequately protect their private interests themselves.

\section{Conclusion}

An adopted child will probably prevent lapse of a legacy or devise, either under existing case law, or under the wording of the statutes, in thirty-six ${ }^{84}$ of the forty-seven ${ }^{85}$ jurisdictions with anti-lapse statutes. The Indiana, ${ }^{86}$ Pennsylvania ${ }^{87}$ and Arkansas ${ }^{88}$ statutes are the most effective from the standpoint of this particular problem because the answer is in the anti-lapse acts themselves. However, from the viewpoint of increasing all rights of adopted children under inheritance laws, an act defining the terms "issue," "descendants," "heirs," and "children" as used in all statutes to include adopted children would be more desirable.

Until the legislatures act, however, the inheritance rights of adopted children must remain with the courts, which can profitably follow the example set by the North Carolina Supreme Court ${ }^{89}$ in applying a clear and simple test which will result in broad inheritance rights for adopted children.

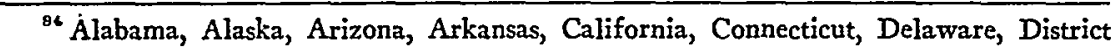
of Columbia, Florida, Georgia, Ilinois, Indiana, Iowa, Maine, Maryland, Michigan, Minnesota, Mississippi, Nebraska, Nevada, New Hampshire, New Jersey, New York, North Carolina, North Dakota, Ohio, Oklahoma, Oregon, Pennsylvania, Rhode Island, South.Carolina, Tennessee, Virginia, Washington, West Virginia and Wisconsin.

${ }^{85}$ The four states which do not have anti-lapse statutes are Hawaii, Louisiana, New Mexico and Wyoming.

${ }^{80}$ IND. ANN. STat. \& 6-60I(g)(2) (1953).

${ }^{87} \mathrm{P}_{\mathrm{A}}$. Stat. ANN. tit. 20, § I80.14(6) (Supp. 1961).

"ARk. Stat. ANn. § 60-410(b) (Supp. 196I).

50 Ḧeaden v. Jackson, 255 N.C. 157,120 S.E.2d 598 (1961). 